\title{
Feminists and their perspectives on the church fathers' beliefs regarding women: An inquiry
}

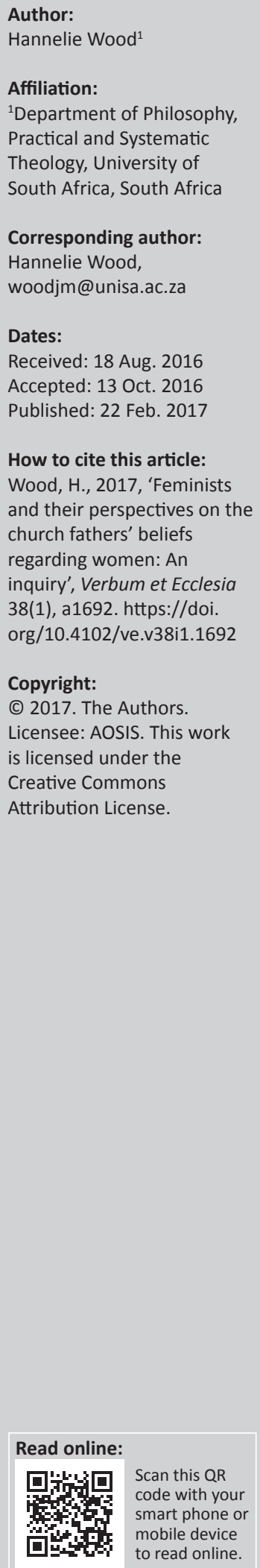

The church fathers and their views on women were influenced substantially and significantly by philosophical voices, such as that of Aristotle and Plato, amongst others. A brief account on Aristotle's and Plato's ideas about women, from feminist perspectives, will be touched upon. The article furthermore explores feminist voices, regarding the church fathers' thinking about women, and how these views contributed to women's subordination and domination. The research will focus on the many varied views on women held by Latin church fathers, such as Tertullian (c. 155-255), Cyprian (c. 200-258 AD), Jerome (c. 347-419), Ambrose (c. 339-397) and Augustine (354-430), and the Greek church fathers, such as Clement of Alexander (c. 150-215), Origen (c. 185-254) and Chrysostom (c. 347-407), from the perspective of feminists. It will be contended that an insensitive and too early denunciation of the early church fathers as misogynists often occurs in women's history without taking into consideration the church fathers' philosophical and social contexts and, hence, the opinions that formed their views. One such theory that helped to shape the church fathers' views about women is the classic medical theory, and this therefore merits a brief discussion. Another important point one has to take into account is the church fathers' perceptions of the carnal (sexual) and the spiritual world that shaped their views about women.

Intradisciplinary and/or interdisciplinary implications: History teaches us what people before us did, what their intentions were and where they failed or went wrong. If historical viewpoints about women reflect women's subordination and oppression, they force women to discover their roots and their past. The church fathers, however, inherited a long tradition of debates, beliefs, and arguments regarding women's moral, intellectual, and natural capacities. Therefore, generalised, simplified, and unsympathetic views about the ancient philosophers and the church fathers' views on women often leads to the ineffective understanding of these men and their context.

\section{Introduction}

Women were oppressed, marginalised and dominated in a male-centred world. In a patriarchal society, men are viewed as superior, stronger and more rational than women, and that God created men to dominate. In the same patriarchal society, women are viewed as deviant, incomplete, physically mutilated, emotionally dependent, unstable, naturally weaker, unintelligent and rationally inferior. In brief, patriarchy is a system in which women experience discrimination, subordination and physical, mental and spiritual violence, as well as abuse and oppression (Wood 2013:155).

We cannot deny or ignore that patriarchy exists, and, from a feminist point of view, patriarchy as a system is intrinsically evil. The church fathers and their views on women were influenced substantially and significantly by philosophical voices, such as that of Aristotle and Plato, amongst others. Therefore, a brief account on Aristotle's and Plato's ideas about women will be touched upon. The article will furthermore explore feminist voices, regarding the church fathers' thinking about women, and how these views have contributed to women's subordination and domination. Special attention will be given to the Latin church fathers, such as Tertullian (c. 155-255), Cyprian (c. 200-258 AD), Jerome (c. 347-419), Ambrose (c. 339-397) and Augustine (354-430), and the Greek church fathers, such as Clement of Alexander (c. 150-215), Origen (c. 185-254) and Chrysostom (c. 347-407).

I also contend that an insensitive and too early denunciation of the early church fathers as misogynists often occurs in women's history, and this is carried out without taking into

Note: This article is partially based on the author's thesis of the degree of Doctor of Theology in Systematic Theology at the University of South Africa, South Africa, with promoter Prof. Daniël Petrus Veldsman, available here: http://uir.unisa.ac.za/bitstream/ handle/10500/8820/thesis_wood_jm.pdf?sequence=1 
consideration the church fathers' social context and the opinions that formed their views on women. One such theory that helped to shape the views of the church fathers, in Late Antiquity, about women is the classic medical theory (Barker 2014:6). The classic medical theory affected the church father's perceptions about women and therefore merits a brief discussion. Another important issue one has to take into account is the church fathers' perceptions of the carnal (sexual) and the spiritual world that shaped their views about women (Salisbury 1991).

For the purpose of this article, it is important to note that secondary sources are an integral part of this article which mostly portrays the views of feminists, whether they are positioned in the context of the first wave, second wave or third wave feminism.

\section{Plato and Aristotle}

Ancient Greeks held a very low opinion of women in such a way that the latter were required to be passive homebodies and were mainly considered responsible for bringing forth and raising children (Du Bois 2007:1). Greek biology believed that women were inferior to men and labelled them essentially as childbearers and housekeepers. Greek philosophers such as Plato and Aristotle reflected and reinforced the discourse on women's status throughout history, and their views on women also influenced the views and thoughts of the church fathers about women in Christian theology. Ruether (1985) says that traditional Christian dualism originated partly in ancient Greece from the metaphysical theories of Plato and Aristotle. She says the following:

The influence of ... Aristotelian biology on Christian theology ... can hardly be underestimated. Aristotle's biology gave 'scientific expression' to the basic patriarchal assumption that the male is the normative and representative expression of the human species and the female is not only secondary and auxiliary to the male but lacks full human status in physical strength, moral selfcontrol, and mental capacity. The lesser 'nature' thus confirms the female's subjugation to the male as her 'natural' place in the universe. (p. 65)

Gonzales (2007:21) argues that Plato (428-347 BC) was the first philosopher to develop a substantial understanding of male and female identity; she also states that Plato's views were grounded in his mind-body dualism where the soul or mind was not necessarily reflected in the body, but significantly distant from it.

In Plato's theory on the creation of humankind, souls were originally thought to be implanted in male bodies and given volition, sensation and emotion. Consequently, this paved the way for gender inequality. She also states that although Plato was of the opinion that women were capable of performing the same duties as men, he also maintained that women are weaker than men and that in order for women to become rulers they were required to divorce themselves from their private and biological roles as mothers (Yen 2003:1-22).
Kasubhai postulates that the placement of the creation of women in concurrence with the creation of birds, mammals, reptiles and fish is an indication of Plato's negative views on women. Plato has had very strong views on the inferiority of women. He believed that, as they were not fully human and not capable of reasoning, their only hope was to return to earth again as men to perfect themselves. Plato also describes women as those men who have fallen prey to their irrational and emotional sides, and that as inferior beings, women must be ruled by men (Kasubhai 1996:37, 47).

Plato and his views on women are not always perceived to be negative. Lee states that in his Book $V$ of the Republic, Plato refers to the functions in an ideal state that should to be distributed according to a person's nature, disposition and ability (Lee 2003:369e-370d). After some inquiry, Plato concluded that despite physiological differences that separate men and women, both have equal natural abilities to be guardians (rulers) of the city, and that neither men nor women should be excluded from these duties (Lee 2003:454e-457a). On the other hand, although he was of the opinion that because women are traditionally viewed as physically weaker than men, they should share in the lighter duties (Lee 2003:457b).

During Aristotle's lifetime (384-322 BC), both slaves and women were not highly regarded. In male texts and through masculine language, the male presided as the dominant figure. Thus, in his Politics, he describes men as superior to women and, therefore, men should rule over women. Aristotle believed that women do not actually want to participate in political affairs. He concluded, therefore, that women were better off being ruled over by men. In his Politics, Aristotle also reasoned that men, by their very nature, are more capable of leadership than women. Aristotle also maintained that men should rule over their wives as they lacked authority (Kraut 2002:249).

In an article, Ruether states that Aristotle in his Politics was of the opinion that men are superior to women because of their physical differences and that a man's courage is displayed through the commanding of the obeying woman (Ruether 2011:65). Women are smaller, shorter lived, weaker and less articulated than men and, therefore, women should be ruled by men as determined by the natural order of the universe. Men actively provide the soul of offspring, whereas women only passively provide the matter. The matter is less divine than the form and, therefore, women are inferior to men and should be confined to the household (Ruether 2011:65).

Aristotle placed women in the same category as slaves and non-Greeks. He perceived them all to be naturally servile and created merely for procreation. Again, he believed that one should look upon the female state as being reformative (Strachan \& Strachan 1985:2).

Women, according to Aristotle, were defective beings, lacking mental volition and physical powers and therefore were not able to exercise public leadership in the church and society 
(Ruether 2011:65). Aristotle's texts are naturally perceived to be misogynistic as his abiding views on women were that they were inherently inferior to men. To cite Freeland's catalogue:

Aristotle says that the courage of a man lies in commanding, a woman's lies in obeying; that 'matter yearns for form, as the female for the male and the ugly for the beautiful'; that women have fewer teeth than men; that the female is an incomplete male or 'as it were, a deformity': which contributes only matter and not form to the generation of offspring; that in general 'a woman is perhaps an inferior being': that female characters in a tragedy will be inappropriate if they are too brave or too clever. (Freeland 1994:145-146)

\section{The church fathers' perceptions of women}

The Latin and the Greek church fathers' writings reflect the times and conditions within which they lived. It finds expression in their dualistic view of the soul and body: God and nature, and male and female. During the period 1-590 AD, Christianity became firmly rooted in the Graeco-Roman culture and this period marked a concerted effort to restrict the role of women in the church and society. This is reflected in the above discussion on Plato and Aristotle. Women were allowed to engage in charitable works, but were forbidden to undertake religious instruction or to administer the sacraments. Women were not considered equal to men (Isherwood \& McEwan 2001:57-58).

Views of the church fathers, such as the Latin church fathers Tertullian, Cyprian, Jerome and Augustine - and the Greek church fathers - Clement of Alexander, Origen and Chrysostom - were not only built upon the anthropology of Plato (428/427-348/347 BC) and Aristotle (384-322 BC) but also on Scripture and especially those of Paul. 1 Corinthians 14:34-35 was often cited and used as a justification for gender inequality. They based their views of women on texts such as Genesis 1:27, Genesis 2:20-23 and Genesis 3:1-24 in the Old Testament. In the New Testament, gender inequality supporting texts included 1 Timothy 2:8-15, 1 Corinthians 11:7-9, 1 Corinthians 14:33-35 and Ephesians 5:22-23. Lerner points out that these texts were interpreted in different ways, either literally or allegorically. Literally, they pointed to the innate inferiority of women and, allegorically, they referred to the human mind whereby the higher intellect belongs to men and the lower intellect belongs to women (Lerner 1993:141). Lerner (1993:140-143) states that according to the church fathers, women were responsible for sin as the root of all evil. Knight (1974:117) contends that the creation story implies women's subordination and the myth of the virgin birth contributed to sex being viewed as unclean and displeasing to God.

The fusion of all women with Eve came with the apostolic sanction, and Eve become the scapegoat for the limiting of women's activities and authority and to generally justify women's submission to men (Clark 1994:168). Sawyer (1996:149) offers three arguments whereby the church fathers identified women with Eve. Firstly, women were viewed as the second sex. Genesis 2 states that Eve was created after Adam, and Genesis 2:18 became the proven text to maintain the sexual hierarchy in Christianity. Paul's epistles were applied to define the position of women in the family as well as in the church. Eve became the second sex for two reasons: she was created after Adam and, because she was disobedient, she does not represent the image of God (Sawyer 1996:149). The second argument is the blaming of Eve for introducing sin into the world. Passages such as 2 Corinthians 11:3 and 1 Timothy 2:14 became the argument for the subordination of women and their inferior status within the church (Sawyer 1996:153). As the first sinner, Eve was the embodiment of all women and therefore women fell outside the redemptive power of Christ (Sawyer 1996:154). Women could only be redeemed through childbearing and their very existence was only for the sake of procreation. A third argument offered by Sawyer is that Christianity produced two kinds of women: Eve and Mary. Irenaeus saw both similarities and contrasts between Eve and Mary, the mother of Jesus. Sawyer (1996) cites a leading apologist Irenaeus' (c. 120-200) Against Heresies, as an example:

Eve, having become disobedient, was made the cause of death both for herself and for all the human race. Thus also Mary had a husband selected for her and nonetheless was a virgin, yet by her obedience she was made the cause of salvation both for herself and for all the human race. For this reason the law calls a woman engaged to a man his wife, while conceding that she is still a virgin. This indicates a link that goes from Mary back to Eve. (p. 156) and

... Moreover, the knot of Eve's disobedience was loosened through the obedience of Mary. For what the virgin Eve bound through unbelief, this the Virgin Mary loosed through faith. (p. 156)

In his De Culta Feminarum, cited in Ruether (1974:157), Tertullian, a North African theologian and montanist, claimed that Eve was the originator of sin and therefore all women carried the curse of Eve:

If there dwelt upon earth a faith as great as is the reward of faith which is expected in the heavens, no one of you at all, best beloved sisters, from the time that she had first known the Lord, and learned (the truth) concerning her own (that is, woman's) condition, would have desired too gladsome (not to say too ostentatious) a style of dress; so as not rather to go about in humble garb, and rather to affect meanness of appearance, walking about as Eve mourning and repentant, in order that by every garb of penitence she might the more fully expiate that which she derives from Eve, the ignominy, I mean, of the first sin, and the odium (attaching to her as the cause) of human perdition. In pains and in anxieties do you bear (children), woman; and toward your husband (is) your inclination, and he lords it over you. And do you not know that you are (each) an Eve? The sentence of God on this sex of yours lives in this age: the guilt must of necessity live too. You are the devil's gateway: you are the unsealer of that (forbidden) tree: you are the first deserter of the divine law: you are she who persuaded him whom the devil was not valiant enough to attack. You destroyed so easily God's image, man. On account of your desert - that is, death - even the Son of God had to die. (Tertullian in Lerner 1993:141) 
Jerome, a Christian apologist, shared the views of his contemporaries about women. Women's wombs were the soil that received the male seed and for Jesus Christ to become human. He had to endure the revolting conditions of the womb. He claimed that for women to become men, they would have to abstain from sex, although through childbearing, women can escape the punishment they receive because of the sin of Eve (Knight 1974:120). Jerome held Eve and, as a consequence, every woman responsible for all heresy. He claimed that men such as Nicholas of Antioch, the seducer of all impurity, was followed by crowds of women; Simon Magnus founded his sect with the help of Helene the prostitute; Marcion used women to prepare the minds of men to join his sect (Keane 1987:3). Jerome viewed women as the root of all evil and said:

Adam was first formed, then Eve; and Adam was not beguiled, but the woman being beguiled hath fallen into transgression: but she shall be saved through the child-bearing, if they continue in faith and love and sanctification with sobriety. (cited in Phelips 1931:203)

Sawyer (1996:150) observes that in his interpretation of 1 Corinthians 11:7-9, Chrysostom, Archbishop of Constantinople, stated that women lost their divine image because of the fall and are, therefore, subservient to men. Chrysostom in his Homily IX (1843) contended that because Eve sinned, all women were punished with subjection. He writes:

The woman [Eve] taught once, and ruined all. On this account therefore he saith, let her not teach. But what is it to other women, that she suffered this? It certainly concerns them; for the sex is weak and fickle, and he is speaking of the sex collectively. For he says not Eve, but 'the woman', which is the common name of the whole sex, not her proper name. Was then the whole sex included in the transgression for her fault? As he said of Adam, 'After the similitude of Adam's transgression, who is the figure of Him that was to come' (Rom. v. 14); so here the female sex transgressed, and not the male. (p. 71)

Although Clement of Alexandria accepted the reality of sex, he advocated that it is only to fulfil God's will for procreation. He denounced and condemned physical pleasure as well as the femaleness of women (Ide 1984:66). Clement of Alexandria's sexism was carried over in his writings and he contended that the only strong person was a man. In his Stromata he writes:

... His beard then is the badge of a man and shows him unmistakably to be a man. It is older than Eve and is the symbol of the stronger nature. By God's decree, hairiness is one of man's conspicuous qualities, and at that, it is distributed over his whole body. Whatever smoothness or softness there was in him God took from him when he fashioned the delicate Eve from his side to be the receptacle of his seed, his helpmate both in procreation and in the management of the home. What he left (remember he lost all traces of hairlessness) was manhood and reveals that manhood. His characteristic is action; hers, passivity. For what is hairy by nature is drier and warmer than what is bare; therefore, the male is hairier and more warm-blooded than the female; the uncastrated, than the castrated; the mature, than the immature. Thus it is a sacrilege to trifle with the symbol of manhood. (Clement of Alexandria, in Ide 1984:66)
In Augustine's interpretation of Paul's theology, he concluded that humans had become alienated from their own best potential and had to get it back in a gift - the gift being the crucifixion of Jesus Christ. As a result, Eve became the origin of sin and the cause of Adam's fall. All women became Eve's daughters, and therefore, became the bearers of sin (Ruether 1983:167). Augustine believed that there was sex in Eden and that it was good and without lust. Lust became the product of sin after Eve ate the forbidden apple (Ide 1984:92). He blamed women for the fall and for the eviction of Adam and Eve from paradise on Eve (RankeHeinemann 1991:185).

Women were not only regarded as the cause of all sin, they were also seen as inferior and weak in both mind and character and also as not having been created in the 'image of God'. Keane (1987:2) said that women, in the history of the church, represented the imago Dei in a secondary sense. 1 Corinthians 11:7-9 became the underpinning text of the church fathers' views that women were not made in the image of God (Sawyer 1996:149-150). The phrases 'becoming male' and 'women turned into man' became important themes and were frequently used in early Christian literature as well as in non-Christian texts such as those of the Koine culture (Vogt 2003:49). Femininity and masculinity stood in contrast and the phrase 'becoming male' refers to the development from a lower to a higher state of moral perfection (Vogt 2003:49).

Origen's anthropology distinguished between male and female as so created by God. God created male and God created female, and he maintained that there is a sharply defined contrast between male and female (Vogt 2003:52). Origen, however, does not connect the female with the image of God. For Origen, human beings were created of spirit and soul and the spirit is described as masculine and the soul as feminine; therefore, the masculine is higher and in quality better than the feminine (Vogt 2003:53). Origen postulates that when God created man in his image, as male and female, the female is connected with 'fecundity' and not directly with the imago Dei, whereas for males, being in the image of God is 'constitutive' (Vogt 2003:52).

Tertullian, as cited in Ide (1984:75-78), stated in his Prescription Against Heretics that only men are created in the image of God and that they were innocent victims of the 'wiles and evils of women'. He forbade women to teach, baptise, become priests, and/or speak in. Furthermore, he demanded that women's heads to be covered.

Augustine, as cited in Børresen (1995), explains the nature of woman in the image of God as follows:

... the wife with her husband is the image of God, so that the totality of this human substance forms a single image; but when woman is considered as man's helpmate, a state which belongs to her alone, is not the image of God. By contrast, man is the image of God by being solely what he is, an image so perfect, so whole, that when woman is joined with him it makes only one image. (p. 170) 
Miles (1991:96) observes that, for Augustine, women were not created in the image of God but only in his likeness. This view of Augustine supported the idea that women were weak and have a greater tendency to sin, and even before they sin, women must be submissive and must, therefore, be ruled by their husbands. Augustine, as cited in (Lerner 1993), says:

I have said, when I was treating the nature of the human mind, that the woman together with her husband is in the image of God ... but when she is referred to separately to her quality of 'help-meet', which regards the woman herself alone, then she is not the image of God, but as regards the man alone, he is the image of God as fully and completely as when the woman too is joined with him in one. (p. 141)

Chrysostom did not include women in the natural image of God, because this image is one of power and dominion, both of which woman has been deprived of by God and society (Tavard 1973:48ff.).

Feminists argue that the church fathers defined the status of women and sought to restrict and limit women's influence in society. Women were not only blamed for sin but also viewed by the church fathers as the weaker sex, inferior and creatures of lust.

The central themes of Clement of Alexandria's anthropology are based on human nature against that of sexually determined nature, as well as on the salvation of believers and their journey to salvation (Vogt 2003:49). God created different sexes and, as such, sexual desire becomes the root of all evil (Vogt 2003:50-51). Women are inferior to men, and he believed that his contempt for women was a universal point of view (Ranke-Heinemann 1991:127). He maintained in The Stromata that a woman could only achieve perfection in this life if she frees herself from the cravings of the flesh (cited in Ranke-Heinemann 1991:130). Because virtue only belongs to the men and because women are 'licentious and unjust', they have to 'practice self-restraint and righteousness' and only then can they become more male-like by renouncing cravings of the flesh. He further writes on virtue, stating that:

it belongs to the male alone to be virtuous, and to the woman to be licentious and unjust. Accordingly woman is to practice self restraint and righteousness, and every other virtue. ... We do not say that woman's nature is the same as man's, as she is woman. ... Pregnancy and parturition, accordingly, we say belong to woman, as she is woman, and not as she is a human being. (Clement of Alexandria in Ide 1984:66)

Origen disapproved of the sexual act even within marriage (Phelips 1931:203). Weinrich (1991:258) states that Origen described women as 'worse than animals' because of their constant state of lust. In his commentary on 1 Corinthians 14:34-35 on women speaking in public, Origen argued that women are not permitted to do so as female prophets never spoke publicly. In Origen's teachings, he refers to the 'interior man' and the 'soul or anima'. Whilst the interior man refers to the men, the soul or anima refers to women. The male part is higher and more moral than that of women who are inclined to lean towards the senses and are, therefore, unfaithful, weak, lazy and dependent on men. However, when the woman is ruled by her spirit, she is male and when she is ruled by her soul she is female. Origen believed God favoured the male (Keane 1987:12; Vogt 2003:59). Women, according to Origen, can do nothing manly, but do have the potential to change into perfect men. The soul of a woman can change to become a 'perfect man'. He uses the metaphor of a 'perfect man' for humans who have not reached 'a state of perfection' and these are the girls who accompany the bride of the church. The angels are those who have attained perfection and are 'represented by young men with the Bridegroom'. The souls (female) can evolve from a sexual female stage to the highest masculine stage when they are freed from their femaleness and they can then become perfect men. On the ordination of women as priests and prophetesses, Origen relied upon 1 Corinthians 14:34-35 to prevent women from these ministries. He claimed that although women such as Marian and Deborah are mentioned in the Gospel, however, they did not speak in church (Vogt 2003:54-55).

On the ordination of women and women being prophetesses, Tertullian acknowledges in the Prescription Against Heretics that although women were active in the church, it was at the cost of men's dignity. Women performed exorcisms, where physicians performed sacraments and were ministers of faith tasks he believed were reserved for men only (McGuire 1999:264). For Tertullian, women were the source of all evil, and he believed that there was nothing good about women, in general or, any woman in particular. In his view, women were responsible for pain, suffering, sin and corruption in both the private and public spheres (Tavard 1973:58-59). Tertullian despised women so much that he warned men against gazing upon them, because it would mean that they would have their immortal souls consigned to hell and would be doomed to never enjoy the security of heaven after death (Tavard 1973:59).

Jerome viewed women as the root of all evil. He declared that a clean body signifies a dirty mind because he found all aspects of sexuality repugnant (Strachan \& Strachan 1985:6). It is often stated that he had a 'love affair with virginity' because he saw virginity as better than marriage (Ide 1984:85). Ide (1984) states:

Unfortunately, many male theologians and other men believed that sexual thoughts, interest, and expression were initiated, generated, and completed when a woman was present, being sexually evil - and yet at the same time not being capable of experiencing the same fullness of sexuality as did man. (p. 88)

Jerome claimed that although marriage is good, virginity is better because men are corrupted through sexual intercourse. It is thus better for men not to get married and to therefore escape the burden of having a wife (Ide 1984:72). In his Letter, to Marcella, he writes:

The women who ought to scandalize Christians are those who paint their eyes and lips with rouge and cosmetics; whose chalked faces, unnaturally white, are like those of idols; upon whose cheeks every chance tear leaves a furrow; who fail to realize that years make them old ... A Christian women should 
blush to do violence to nature, or to stimulate desire by bestowing care upon the flesh. 'They that are in the flesh', the apostle tells us, 'cannot please God'. (Jerome cited in Phelips 1931:203)

Jerome, (cited in Ide 1984) in his letter to Pammachius, Letter, has this to say about marriage:

For it is better that a woman should know one man (though he should be a second husband or a third) than that she should know several. In other words, it is preferable that she should prostitute herself to one rather than to many. (p. 84)

Augustine, in his views on the natural order, states in the Heptateuch, that women were created lesser than man and therefore, they have to serve men as being the greater. Men are superior to women because women were created with a weaker brain. Therefore, the weaker has to serve the stronger. In his Concupiscence, Augustine wrote:

Nor can it be doubted, that it is more consonant with the order of nature that men should bear rule over women, than women over men. It is with this principle in view that the apostle says, 'The head of the woman is the man'; and, 'Wives, submit yourselves unto your own husbands'. (Augustine in Ide 1984:97)

According to Phelips (1931:203), Augustine believed that it was an incontestable social and religious truth that women were subordinate to men. He was of the opinion that it is according to the natural order for men to rule over women and for women to both serve and be subservient to their husbands. For Augustine, nothing was worse than a house where the woman commands and the man obeys; therefore, the husband must always rule over his wife.

Chrysostom described women as weak and flighty, a fault of nature, evil, as temptresses and as mischievous (Knight 1974:121). Chrysostom believed that it was God who maintained the order of each sex. God gave men supremacy as leaders of business of the state, the marketplace, the administration of justice, the government and the military (Lampe 1981:124). Women, on the other hand, were assigned the presidency of the household and other so-called inferior matters (Keane 1987:5). Chrysostom wrote:

Among all the savage beasts none is found to be so harmful as woman. ... The whole of her body is nothing less than phlegm, blood, bile, phlegm and the fluid of digested food. ... If you consider what is stored up behind those lovely eyes, the angle of the nose, the mouth and the cheeks you will agree that the wellproportioned body is only a whitened sepulcher. (cited in Cooper-White 2012:72)

Chrysostom, in the Epistle to the Ephesians, said that the female sex is weak and fickle, and in his Homily on 1 Timothy 2:11-15 he stated:

To such a degree should women be silent, that they are not allowed to speak not only about worldly matters, but not even about spiritual things, in the church. This is order, this is modesty, this will adorn her more than any garments. Thus clothed, she will be able to offer her prayers in the manner most becoming. (Chrysostom in Keane 1987:5)

\section{The classic medical theory and its influence on the church fathers' views about women}

The church fathers' perceptions of women are central to this article. The Hippocrates Corpus offers critical insight into how women were perceived in classical medical theory and can be directly linked to how the church fathers perceived women as being the weaker, inferior and incomplete males. The Hippocratic Corpus and its authors were of Greek origin. The classic medical theory according to Gleason (1995:352) illustrates the inferiority of the female body to that of the male body, that men's bodies were more solid and robust because of the embryonic process, that women's bodies were more imperfect because of their heat deficiency and that women were viewed as incomplete males.

Whilst physicians could physically examine men, they were not allowed to view female anatomy. Hippocratics received their medical knowledge from the traditional practices of whole-body studies (Nutton 2004:57). They believed that to study all psychological, physical and superstitious symptoms, equipped them to diagnose and treat problems. Doctors treated women without the knowledge of how a woman's internal and external anatomy looked like or how it functioned (Nutton 2004:57). This compelled them to rely on verbal descriptions made by men's observations and theoretical ideas concerning women's anatomy as being incapable males (Martin 1995:32). Women were thought of as being more emotional than men and more susceptible to madness. Madness in a woman was caused by a thick vein in her breasts, an indication that a big portion of women's intelligence is confined to their breasts. The sign of a woman who is about to go mad is the excessive blood that collects in her breasts (Hippocratic Corpus, Epidemics II., Vi 19 and 32).

The following are a few examples of the thoughts on the inferiority of women's bodies in the Hippocratic Corpus.

\section{Before conception women were already inferior}

The Hippocratic Corpus contains medical treatises which are associated with the physician Hippocrates (Stewart 1995:584) and is based on perceptions that the human body consists of fire, water, air and earth, and an imbalanced human temperature was the proof of the absence of one of these elements (Martin 1995:148).

According to the theory of the uterus having two chambers, men come from the hot right chamber (considered to be more superior to the left side), whereas women come from the cooler left chamber (Harlow 1998:159). According to the embryonic process theory, the male embryo comes from the right side of the testicle because the blood coming from the right side of the testicle is thicker and hotter than that of the left testicle. For men to produce male embryos, they were advised to bind their left testicle (Rousselle 1988:48). 
Women also have two testicles, but they remained internal and were less perfect (Harlow 1998:159; Rousselle 1988:48).

Whilst the female foetus takes 42 days to form, the male foetus only takes 32 days to form. This is because of the female foetus being weaker than that of the male (Martin 1995:32). As a result, a female foetus being formed in the uterus's cooler part is weaker and fluid and it only starts moving at 4 months, whereas the stronger male foetus starts to move at 3 months (Martin 1995:32).

\section{Women's wombs predetermined the sex of a child}

Because of the wandering womb theory, a woman's womb was thought of as being an oven wherein seeds are baked and as a raging animal roaming in the female body (King 1998:33, 222). Women with wondering wombs display erratic behaviour, and if the womb becomes dry it is attracted to other organs such as the heart, liver and brain to ease its thirst. Suffering from a dry womb will result in women to become voiceless and to lose consciousness (Fantham et al. 1994:188). To avoid this to happen, women are encouraged to have sex. Sex was regarded as a cure for most women's unhealthy conditions (Hippocratic Corpus, On Diseases of Women, II, 125).

Women were advised to watch their diets. Hot and dry diets will produce males, whereas a cool and moist diet will produce females (Martin 1995:32). The scent theory claimed that a wandering womb could be lured back into place by either unpleasant or pleasing odours (King 1998:36). When a woman complained about a blocked nose and sore eyes, she was advised to wash herself with hot water and, if this did not work, she had to pour laurel over her head and fumigate her vagina with sweet smells. By washing themselves with hot water, or by pouring hot oils over their heads, and even wraping bandages around their wombs, women could bring their wondering wombs under control (King 1998:36).

\section{Women have no control over their bodies}

Because women are more porous and draw moisture faster from her belly to her body, they are more inclined to draw blood to their breasts, which prone them to go mad; thus, they are more irrational than men in behaviour (Hippocratic Corpus, Deceases of Women, 1.1). King contest that the wandering womb theory implied control by men over female bodies because they do not have control over their own bodies and that this situation inspired some women to turn out to be masters of their own bodies by choosing celibacy and becoming ascetics (King 1998:36). King, however, also points out that it was often said that the penis was 'selfwilled' which painted a picture of men not being in control of their own bodies. Because the gods bestowed sexual desire onto humans, those humans who proved themselves as unjust became female (King 1998:223).

Menstruation was a result of women's bodies being soft and porous and therefore their bodies' need to drain off the excessive blood causing their bodies to become painful and overheated. Men's bodies did not suffer this condition (DeanJones 2003:201). It was argued that when a woman's womb dried up, it means that the womb was in need of moisture and therefore intercourse was prescribed as a solution to treat a dry womb, and this was believed to contribute to a more healthy body (Martin 1995:223).

Barker (2014:16) states that the Hippocratic Corpus clearly viewed the female as being physically and emotionally weaker than men and, therefore, women needed men to overcome their weaknesses.

\section{The church fathers' perceptions of the carnal (sexual) and the spiritual}

Joyce Salisbury, in her book Church Fathers, Independent Virgins (1991), made an in-depth study of the church fathers' perceptions about sexuality. In this section, I will mainly focus on her work because it offers a thorough account of the church fathers' views and fears on sexuality.

After the birth of Christ and with the spread of Christianity throughout the Roman Empire, Christians started to reconsider the world and, more specifically, the place of sex in the bigger scheme of creation. We have to ask why? Laeuchili (1972:102-113) states that in ancient times, there was a crisis regarding human identity that caused Christians in the Roman world to wrestle with the position humans have in the world. This caused Christians to grapple with questions such as whether sexuality was good or bad, the nature of celibacy, what was sexuality evil and what the nature and character of Christian sexuality is.

Reflecting on these questions and building upon each other's works, the church fathers created a body of thought, which they used in constructing Christian thought on many issues such as human sexuality and celibacy. The church fathers' perception of the carnal (sexual theory) and the spiritual world shaped their views on women (Salisbury 1991:12). Another important issue one has to take into account is the church fathers' theoretical position on their ideal of virginity.

The church fathers understood men to be primarily spiritual and women as carnal (Salisbury 1991:26). Salisbury (1991) says:

The Fathers did not necessarily equate flesh with the visible body. Spirit and flesh were opposite abstract principles that could be understood by their expression in concrete action ... the terms flesh and spirit represented potential states that the body could actualize. The body itself was neutral and could be drawn to either the flesh or the spirit, depending on which urges the individual followed. (p. 12)

For example, Cyprian reminded virgins in the Dress of Virgins that their bodies are spiritual and by the renunciation of the flesh, they dedicated themselves to God (Cyprian 1958:34), and in similar vein, Jerome in To Eustochium (1893:23) and Ambrose in De Virginitate (1895:279-318) referred to virgins' bodies as the temples of God. 
The church fathers connected the fall to sexuality. They regarded Adam and Eve originally to be virgins and after they sinned, they were banned from paradise and were immediately married. Original sin was perceived to be sexual in nature (Salisbury 1991:13). Marriage brought forth sexual consequences. The church fathers contended that in marriage one does not have control over one's own body and one has to satisfy the other's sexual desire and warned against the burdens thereof for women (Salisbury 1991:13). Jerome, in The Perpetual Virginity of the Blessed Virgin Mary, Against Helvidius, says that women in marriage have to care for children, organising their household and have to please their husbands. In his Against Jovinian (1893:386), he says of marriage that 'there is no greater calamity connected with the captivity that to be the victim of another's lust' (Salisbury 1991:13).

Understanding sexuality in strong physical terms, the church fathers warned against giving in to the senses. They used metaphors such as touch, taste, tongue, sight, smell and hearing as metaphors that lure one into lust (Salisbury 1991:18-21). For example, Jerome in his Against Jovinian (1893:350) warned against touching a woman because it can ignite instant fire, and any man striving for spiritual things has to avoid contact with women. Taste was another sense that could cause lust, and Jerome, in his To Eustochium (1893:25), warned against a full belly that could provoke inflamed lust in his To Furia (1893:105-106). In his On the Veiling of Virgins, Tertullian (1951:37) argued that lust is caused by visual stimulation and both men and women who engage in visual stimulation share in the carnal visual experience, but women are to be veiled to avoid sexual pleasure. Smell represented and defined the carnal for Ambrose (1980:17), and he urged women and men to rather breathe the fragrance of the Lord's resurrection. Virgins, who chose a spiritual life over that of the carnal, will benefit in the odour of spirituality, whereas those who choose the carnal shall bore the odour of death. Ambrose and Jerome referred to virgin's bodies as the temple of God, and, in this perception (Salisbury 1991) that:

Just as the incarnation had made Christ's body and blood worthy of veneration, so a spiritual life could convert the individual's body into a vehicle of sanctity. For the Fathers a spiritual life would convert individual bodies into a vehicle of sanctity ... and a spiritual life could bring about a resurrection of the body while on earth, in imitation of the bodily resurrection to come. (p. 13)

The church fathers identified sexual characteristics to help people in their struggles for the spiritual. In this context, Salisbury (1991:19) continues to say that the fear of woman's sexuality and the related fear of what this would do to man's spirituality also extend to a more concrete fear of women's bodies (Salisbury 1991:24).

Salisbury (1991:19) identifies four characteristics of sexuality that were articulated to make people aware of the difficulties in their struggles against the carnal. These are sexuality is natural, it is pleasurable, it is irresistible and it is disgusting and degrading.
The church fathers often warned against the natural state of sexuality as a sign of the fallen humanity and that sexuality was only for the purpose of procreation. For example, Jerome, in To Demetrias (1893:267), warns that for someone to live a chaste and spiritual life, he or she must 'act against nature'. According to Salisbury (1991:19), the church fathers acknowledged that sex was pleasurable, but they also believed it caused the body to be in the carnal realm and it also prevents people to renounce the carnal once sensual pleasures were experienced. As soon as one experienced the carnal, it may become irresistible, habit forming and hard to stop. Therefore, the church fathers encouraged women to become virgins. Once a woman becomes a widow, it will be harder for her to remain chaste (Salisbury 1991:19). Writing on virginity and chastity, and from the spiritual realm, the church fathers believed that sex was disgusting and degrading. Although all these characteristics applied to both sexes, they made a distinction between men (general) and women (specific) living an ascetic life (Salisbury 1991:21).

Salisbury (1991:21) contends that the goals of the church fathers were to urge people to have a disregard for all carnal things and that the "most pleasurable act was considered "foul" and "corruption"'. She also goes on to say that the characteristics of sex, in general, applied to men and women. Sex was the carnal enemy which both male and female ascetics had to fight against.

The division of humanity into male and female was viewed to be parallel to the world, divided into the spiritual (represented by men) and the physical (represented by women). What it is to be a man was determined by the natural place men had in society and because it was thought that men are guided by the spiritual (rational), they had to govern over the carnal (sexual) women. These rational qualities bestowed upon men the power to be the head of the woman and to govern over women. The power of men was perceived to be more visible in his physicality and his manliness in his activities as well as in his relationships with women; men had rugged voices, used rough speech and had shaggy eyebrows (Salisbury 1991:21).

Women belonging to the carnal world were primarily characterised by lust and defined by their sexuality and were often viewed to be more libidinous than men. The church fathers, therefore warned men against temptresses who continuously reproduced Eve's initial temptation of Adam. It is important to note here that women were not viewed to be temptresses out of desire, but that they were viewed as temptresses as part of their carnal nature (Salisbury 1991:23). Ambrose in the De Virginitate (1895:326) stated, for example, that women cannot be blamed for being temptresses because they cannot be blamed for being born as a women.

In conclusion, the church fathers left the carnal women in an ontological state as lustful temptresses and, for example, Tertullian in his Apparel of Women (1951:117) could refer to women as the 'devils gateway'. 


\section{Conclusion}

The importance of the historical context of influential figures such as Plato and Aristotle, the classic medical theory, and perceptions of the carnal (sexual) and the spiritual, lies in the influence they had in shaping the views of the church fathers on women. History teaches us what people before us did, what their intentions were and where they failed or went wrong. What is undeniably clear from these discussions is that a bleak and grim picture emerges from feminist's perspectives in the historical studies of women. If these historical viewpoints about women reflect women's subordination and oppression, they force women to discover their roots and their past. With this comes the right to redefine, to decide and to act upon freedom from oppression, and to ultimately create emancipation.

Although we see through our own experience, beliefs, and traditions, no interpretation may be disconnected from its social context. In our analysis of particular cultures and societies, we always have to be conscious of our own biases and personal idiosyncrasies.

We need to understand that the church fathers inherited a long tradition of debates, beliefs and arguments regarding women's moral, intellectual and natural capacities. We need to be aware that a generalised, simplified and unsympathetic view about the ancient philosophers and the church fathers that, women are totally and in every aspect of their being inferior to men, leads to the ineffective understanding of these men and the specific context of their time.

I conclude with a remark from Elizabeth Clark (1994:76) who once stated that the 'most fitting word to describe the church father's attitudes towards women is ambivalence'. But she also states that women were not only looked upon as being “"sick-she-asses" or hideous tape worms' but as mentors and models, honoured for their Christian virtues and being 'exemplars of Christian devotion'.

We as women and men should learn from history so that we may wink at the future with a better sense of what is due to each other.

\section{Acknowledgements Competing interests}

The author declares that she has no financial or personal relationships that may have inappropriately influenced her in writing this article.

\section{References}

Ambrose, 1895, A select library of Nicene and post-Nicene fathers, vol. X, P. Schaff \& H. Wace (eds.), Christian Literature Co., New York.

Ambrose, 1980, On virginity, transl. D. Callam, Peregrina Publishing, Saskatoon, SK.

Barker, K.H., 2014, The perception of women in late antiquity and the impact it had on female asceticism, Unpublished thesis, University of Wales Trinity Saint David.

Børresen, K.E., 1995, Subordination and equivalence. The nature and role of woman in Augustine and Thomas Aquinas, Kok Pharos, Kampen.
Chrysostom, J., 1843, On the epistles of St. Paul the apostle to Timothy, Titus, and Philemon, transl. J.H. Parker, J.G.F. and J. Rivington, London.

Clark, E.A., 1994, 'Ideology, history, and the construction of "Woman" in late ancient Christianity', Journal of Early Christian Studies 2(2), 155-184. https://doi. org/10.1353/earl.0.0121

Cooper-White, P., 2012, The cry of Tamar: Violence against women and the church's response, Fortress Press, Minneapolis, MN.

Cyprian, 1958, 'The dress of virgins', in T.R.J. Deferrari (ed.), Treatises, Fathers of the Church Inc., New York.

Dean-Jones, L., 2003, 'The cultural construct of the female body in classical Greek science', in M. Golden \& P. Toohey (eds.), Sex and difference in ancient Greece and Rome, pp. 183-201, Edinburgh University Press, Edinburgh.

Du Bois, E.C., 2007, 'Plato as a proto-feminist', Transcending Silence Spring 2007, viewed 12 June 206, from http://www.albany.edu/womensstudies/journal/2007/ dubois.html\&gt

Fantham, E., Foley, H.P., Kampen, N.B., Pomeroy, S.P. \& Shapiro, H.A., 1994, Women in the classical world, Oxford University Press, New York.

Freeland, C., 1994, 'Nourishing speculation: A feminist reading of Aristotelian science', in B. Bar On (ed.), Engendering origins: Critical feminist readings in Plato and Aristotle, pp. 145-182, State University of New York Press, Albany, NY.

Gleason, M., 1995, Making men, sophists and self-presentation in ancient Rome, Princeton University Press, Princeton, NJ.

Gonzales, M.A., 2007, Created in God's image. An introduction to feminist theological anthrolopogy, Orbis Books, New York.

Harlow, M., 1998, 'In the name of the father: Procreation and patriarchy', in L. Fox \& J. Salmon (eds.), Thinking men, masculinity and its self-representation in the classical tradition, vol. 7, pp. 43-56, Routledge, London.

Ide, A.F., 1984, Women as priest, bishop and laity in the early Catholic Church to 440 A.D., Ide House Inc, lowa, TX.

Isherwood, L. \& McEwan, D., 2001, Introducing feminist theology, Sheffield Academic Press, Sheffield.

Jerome, 1893, A selected library of Nicene and post-Nicene fathers, vol. VI, P. Schaff \& H. Wace (eds.), Christian Literature Inc., New York.

Kasubhai, M.K., 1996, 'Destabilizing power in rape: Why consent theory in rape law is turned on its head', Wisconsin Women's Law Journal 11, 37-47.

Keane, M.H., 1987, “Woman seen as a "problem" and as "solution" in the theological anthropology of the early fathers: Considering the consequences', paper read at Catholic Theological Society of South Africa, University of South Africa, Pretoria.

King, H., 1998, Hippocrates' woman: Reading the female body in ancient Greece, Routledge, London.

Knight, M., 1974, Honest to man: Christian ethics re-examined, Pemberton, London. Kraut, R., 2002, Aristotle: Political philosophy, Oxford University Press, New York.

Laeuchili, S., 1972, Power and sexuality: The emergence of canon law at the Synod of Elvira, Temple University Press, Philadelphia, PA.

Lampe, G.W.H., 1981, Explorations in theology 8, SCM Press, London.

Lee, D., 2003, Plato, the republic, transl. D. Lee, Penguin, London.

Lerner, G., 1993, The creation of feminist consciousness. From the Middle Ages to eighteen-seventy, Oxford University Press, New York.

Martin, D.B., 1995, The Corinthian body, Yale University Press, New Haven, MI.

McGuire, A., 1999, 'Women, gender, and gnosis in gnostic texts and traditions', in R.S. Kraemer \& M.R. D’Angelo (eds.), Women and Christian origins, pp. 257-299, Oxford University Press, Oxford.

Miles, M.R., 1991, Carnal knowing: Female nakedness and religious meaning in the Christian west, Vintage Books, New York.

Nutton, V., 2004, Ancient medicine, Routledge, London.

Phelips, V., 1931, The churches and modern thought, Watts \& Co., London.

Ranke-Heinemann, U., 1991, Eunuchs for the Kingdom of Heaven - The Catholic Church and sexuality, Doubleday/Penguin, Hamburg.

Rousselle, A.P., 1988, On desire and the body in antiquity, Basil Blackwell, New York.

Ruether, R.R. (ed.), 1974, Religions and sexism: Images of women in the Jewish and Christian traditions, Simon \& Schuster, New York.

Ruether, R.R., 1983, Sexism and God-talk: Toward a feminist theology, Beacon Press, Boston, MA.

Ruether, R.R., 1985, Woman guides: Readings towards a feminist theology, Beacon Press, Boston, MA.

Ruether, R.R., 2011, 'Should women want women priests or women-church?', Feminist Theology 20, 63-72. https://doi.org/10.1177/0966735011411814

Salisbury, J.D., 1991, Church fathers, independent virgins, New Left Books, London.

Sawyer, D.F., 1996, Women and religion in the first Christian centuries, Routledge, London.

Stewart, A., 1995, 'Imag(in)ing the other: Amazons and ethnicity in fifth-century Athens', Poetics Today 16(4), 571-597. https://doi.org/10.2307/1773366

Strachan, E. \& Strachan, G., 1985, The devil's gateway. Chapter 6 in freeing the feminine, Labarum Publications, Dunbar.

Tavard, G.H., 1973, Woman in Christian tradition, University of Notre Dame Press, Notre Dame. 
Tertullian, 1951, The ante-Nicene fathers, vol. IV, A. Roberts \& J. Donaldson (eds.) W.B. Eerdmans Publishing, Grand Rapids, MI.

Vogt, K., 2003, 'Becoming male: One aspect of an early Christian anthropology', in J.M. Soskice \& D. Lipton (eds.), Feminism and theology: Oxford readings in feminism, pp. 49-61, University Press, Oxford.

Weinrich, W., 1991, 'Women in the history of the church', in J. Piper \& W. Grudem (eds.), Recovering Biblical manhood and womanhood, pp. 252-265, Crossway, Wheaton, Illinois.
Wood, J.M., 2013, Patriarchy, feminism and Mary Daly: A systematic-theological enquiry into Daly's engagement with gender issues in Christian theology, Doctoral dissertation, University of South Africa, Pretoria.

Yen, R.J., 2003, 'Gender in Judeo-Christian tradition: A critique on Christian feminist philosophies and a presentation of the loyalist view', Quodlibet Journal 5(2-3), viewed 04 November 2010, from http://www.quodlibet.net/articles/yen-gender. shtml 